(c) 2017, THE AUTHORS. Published by FASS and Elsevier Inc. on behalf of the American Dairy Science Association ${ }^{\circledR}$.

This is an open access article under the CC BY-NC-ND license (http://creativecommons.org/licenses/by-nc-nd/3.0/).

\title{
Ethyl-cellulose rumen-protected methionine enhances performance during the periparturient period and early lactation in Holstein dairy cows
}

\author{
F. Batistel, ${ }^{*}$ J. M. Arroyo, ${ }^{\star} †$ A. Bellingeri, ${ }^{*}$ L. Wang,‡ B. Saremi,§ C. Parys,§ E. Trevisi,\# F. C. Cardoso, \\ and J. J. Loor*1 \\ *Department of Animal Sciences and Division of Nutritional Sciences, University of Illinois, Urbana 61801 \\ †Departamento de Nutrición Animal, Instituto de Producción Animal, Facultad de Veterinaria, Universidad de la Republica, Ruta 1 km 42.5, \\ 80100 , San José, Uruguay \\ ‡Department of Animal Science, Southwest University, Rongchang, Chongqing, 402460, P. R. China \\ $\S$ Evonik Nutrition and Care GmbH, 63457 Hanau-Wolfgang, Germany \\ \#lstituto di Zootecnica, Facoltà di Scienze Agrarie Alimentari ed Ambientali, Università Cattolica del Sacro Cuore, Piacenza 29122, Italy
}

\begin{abstract}
The onset of lactation in dairy cows is characterized by severe negative energy and protein balance. Increasing Met availability during this time may improve milk production, hepatic lipid metabolism, and immune function. The aim of this study was to evaluate the effect of feeding ethyl-cellulose rumen-protected methionine (RPM; Mepron, Evonik Nutrition and Care GmbH, Hanau-Wolfgang, Germany) on the performance of dairy cows during prepartum and earlylactation periods. Sixty multiparous Holstein cows were used in a block design and assigned to either a control or an ethyl-cellulose RPM diet. Ethyl-cellulose RPM was supplied from -28 to $60 \mathrm{~d}$ relative to parturition at a rate of $0.09 \%$ and $0.10 \%$ of dry matter during the prepartum and postpartum periods, respectively. That rate ensured that the ratio of Lys to Met in metabolizable protein was close to 2.8:1. Cows fed ethyl-cellulose RPM had dry matter intakes (DMI) that were $1.2 \mathrm{~kg} / \mathrm{d}$ greater during the prepartum period and consequently had overall greater cumulative DMI than cows in the control group. Compared with controls, during the fresh period (1-30 d in milk; DIM) feeding ethyl-cellulose RPM increased DMI by $1.7 \mathrm{~kg} / \mathrm{d}$, milk yield by 4.1 $\mathrm{kg} / \mathrm{d}$, fat yield by $0.17 \mathrm{~kg} / \mathrm{d}$, milk protein yield by 0.20 $\mathrm{kg} / \mathrm{d}, 3.5 \%$ fat-corrected milk by $4.3 \mathrm{~kg} / \mathrm{d}$, and energycorrected milk by $4.4 \mathrm{~kg} / \mathrm{d}$. Although ethyl-cellulose RPM supplementation increased milk protein content by 0.16 percentage units compared with the control during the fresh period, no differences were observed for milk fat, lactose, and milk urea nitrogen concentration. During the high-producing period (31-60 DIM),
\end{abstract}

Received February 4, 2017.

Accepted May 14, 2017.

${ }^{1}$ Corresponding author: jloor@illinois.edu cows fed ethyl-cellulose RPM increased DMI and milk yield by 1.45 and $4.4 \mathrm{~kg} / \mathrm{d}$, respectively. Ethyl-cellulose RPM also increased fat yield by $0.19 \mathrm{~kg} / \mathrm{d}$, milk protein yield by $0.17 \mathrm{~kg} / \mathrm{d}, 3.5 \%$ fat-corrected milk by $4.7 \mathrm{~kg} / \mathrm{d}$, and energy-corrected milk by $4.8 \mathrm{~kg} / \mathrm{d}$ compared with controls. Ethyl-cellulose RPM supplementation reduced plasma fatty acids in the fresh period and decreased $\gamma$-glutamyl transferase, indicating better liver function. In conclusion, when lysine was adequate, feeding ethyl-cellulose RPM to achieve a ratio close to $2.8: 1$ in metabolizable protein improved dairy cow performance from parturition through 60 DIM. The greater milk production was, at least in part, driven by the greater voluntary DMI and better liver function.

Key words: methionine, milk protein, postpartum, transition period

\section{INTRODUCTION}

Despite the prodigious output of research on nutrition and physiology of dairy cows, the transition period remains a challenging phase during which metabolic disorders continue to occur at economically significant rates (Overton and Waldron, 2004). During the transition period cows experience several stressful events, including regrouping, dietary changes, parturition, and the onset of lactation (Sun et al., 2016). Following parturition, cows enter a period of negative energy and protein balance because they cannot consume enough DM to support the requirements for lactation (NRC, 2001). Although extensive research has been conducted focusing on reducing negative energy balance, less emphasis has been put on overcoming protein and indispensable AA imbalances. Previous research suggests that increasing RUP during late gestation improves subsequent lactation performance (Huyler et al., 1999; Greenfield et al., 2000). The RUP fraction is important as a source of EAA for the mammary gland and other 
tissues, such as liver and skeletal muscle (Osorio et al., 2013). Therefore, an adequate profile and amount of EAA in RUP is crucial for a successful transition into and maintenance of an optimal lactation.

Methionine typically is the first-limiting AA for lactating cows (NRC, 2001). Among the various biological functions besides milk protein synthesis for which Met availability is important, some of the most relevant to the transition period include lipoprotein synthesis in liver, antioxidant synthesis, and synthesis of immunerelated proteins (e.g., acute-phase proteins; Osorio et al., 2013; Zhou et al., 2016a). Previous studies have observed beneficial effects of rumen-protected Met (RPM) on performance (Chen et al., 2011; Osorio et al., 2013) and immunometabolic status (Osorio et al., 2014; Zhou et al., 2016a) of dairy cows during the transition period. However, in those studies the effects of RPM on lactation performance were focused only on the immediate postpartum period up to 30 DIM. Knowledge of the potential effect of nutritional strategies that commence in the last few weeks of the dry period (e.g., the close-up) through peak lactation is essential because each additional kilogram of milk secreted at peak production results in approximately 200 $\mathrm{kg}$ more milk during the lactation (Roche et al., 2013). Therefore, determining the effects of RPM supplementation not only during the peripartal period but also through peak lactation is of particular importance.

Different sources of RPM might elicit different responses due to inherent differences in either coating system or effectiveness of the coating system (Patton, 2010). Therefore, our general hypothesis was that feeding ethyl-cellulose RPM starting at $4 \mathrm{wk}$ from expected parturition through 60 DIM would improve overall lactation performance not only during the peripartal period but also through peak lactation. The objective of this study was to evaluate the effect of feeding ethylcellulose RPM on the performance of dairy cows during the peripartal and early-lactation periods.

\section{MATERIALS AND METHODS}

\section{Animal Housing and Care}

The Institutional Animal Care and Use Committee at the University of Illinois (Urbana; protocol no. 14270) approved all experimental procedures. The experiment began on October 25, 2015, and ended on October 10, 2016. All cows were housed in a freestall system equipped with gate system (American Calan Inc., Northwood, NH) during the prepartum period. After parturition, all cows were housed in tiestalls. Cows were fed once daily $(1300 \mathrm{~h})$ at $120 \%$ of expected intake and milked 3 times daily (at 0600, 1400, and 2200 h). Stan- dard reproduction and health herd checks and breeding practices were maintained during this study.

\section{Design and Treatment Diets}

Sixty multiparous Holstein cows from the University of Illinois Dairy Research Farm were used in a randomized complete block design experiment with 30 cows per treatment. Cows were blocked by the expected parturition day, and the blocks were balanced by parity, previous 305-d milk yield, and BCS. The BCS used to block cows was measured at $-30 \mathrm{~d}$ before parturition using a 1 -to- 5 scale $(1=$ thin, $5=$ fat $)$ in increments of 0.25 . Cows within each block were randomly assigned to 1 of the 2 treatments. Treatment diets were a basal control diet with no Met supplementation or the basal diet plus ethyl-cellulose RPM (Mepron, Evonik Nutrition and Care GmbH, Hanau-Wolfgang, Germany). Ethyl-cellulose RPM was supplied from -28 to $60 \mathrm{~d}$ relative to parturition at a rate of 0.09 and $0.10 \%$ of the DMI of the previous day during the prepartum and postpartum periods, respectively. These target values were based on recent experiments demonstrating a benefit in terms of production performance and health of supplementing RPM to achieve a Lys:Met ratio close to $2.8: 1$ during the prepartum and postpartum periods (Osorio et al., 2013; Zhou et al., 2016b). Mepron is a commercial rumen-protected source of DL-Met that resists ruminal degradation through an ethyl-cellulose film coating. Pellets measure $1.8 \times 3 \mathrm{~mm}$ and contain $85 \%$ DL-Met. The intestinal digestibility coefficient and rumen bypass of Mepron is 90\% (Schwab, 1995) and 80\% (Overton et al., 1996); therefore, the cows received $6.1 \mathrm{~g}$ of Met available for absorption/10 $\mathrm{g}$ of Mepron. During the far-off period (from -45 to $-29 \mathrm{~d}$ ), all cows received the same diet (1.33 Mcal/ $\mathrm{kg}$ of DM and $13.9 \%$ $\mathrm{CP}$ ) with no RPM. The basal close-up (from $-28 \mathrm{~d}$ to parturition), fresh (from 1 to $30 \mathrm{~d}$ ), and high-production (from 31 to $60 \mathrm{~d}$ ) diets contained $1.47 \mathrm{Mcal} / \mathrm{kg}$ of DM and $15.3 \% \mathrm{CP}, 1.67 \mathrm{Mcal} / \mathrm{kg}$ of DM and $17.7 \% \mathrm{CP}$, and $1.61 \mathrm{Mcal} / \mathrm{kg}$ of DM and $17.4 \% \mathrm{CP}$, respectively. Diets were mixed daily in a tumble mixer, and ethyl-cellulose RPM was top dressed on the TMR. The ingredient and nutrient compositions of the diets fed are reported in Tables 1 and 2. All rations were formulated to meet cow predicted requirements according to NRC (2001).

\section{Data and Sample Collection and Analysis}

Dry matter of individual feed ingredients and diets was determined weekly and used to adjust the DM of the TMR accordingly. Weekly samples of ingredients and TMR were frozen at $-20^{\circ} \mathrm{C}$ and composited monthly for analysis of CP (AOAC International, 2000; 
Table 1. Ingredient and nutrient composition of far-off (from -45 to $-29 \mathrm{~d}$ ), close-up (from $-28 \mathrm{~d}$ to parturition), fresh (from 1 to 30 DIM), and high-producing (from 31 to 60 DIM) diets

\begin{tabular}{|c|c|c|c|c|}
\hline Ingredient, $\%$ of DM & Far-off & Close-up & Fresh & High producing \\
\hline Alfalfa haylage & - & 6.55 & 7.81 & 10.8 \\
\hline Corn silage & 34.7 & 26.6 & 31.0 & 31.9 \\
\hline Wheat straw & 33.7 & 26.5 & 3.25 & - \\
\hline Corn grain, ground, dry & - & 12.6 & 22.21 & 20.7 \\
\hline Cottonseed & - & - & 2.17 & 1.83 \\
\hline Molasses, beet sugar & - & 4.03 & 5.50 & 4.51 \\
\hline Soybean hulls & 15.7 & 3.46 & 4.25 & 9.96 \\
\hline Soybean meal, $48 \%$ CP & 12.0 & 7.83 & 10.1 & 7.98 \\
\hline Expeller soybean meal $^{1}$ & - & 5.80 & 5.16 & 5.17 \\
\hline Protein supplement $^{2}$ & - & 0.78 & 1.81 & 1.58 \\
\hline Urea & 0.46 & 0.59 & 0.39 & 0.40 \\
\hline Soychlor $^{3}$ & - & 1.23 & - & - \\
\hline Saturated fat supplement ${ }^{4}$ & - & - & 2.25 & 2.14 \\
\hline Limestone & - & - & 1.41 & 0.96 \\
\hline Salt & 0.40 & - & 0.02 & 0.04 \\
\hline Dicalcium phosphate & 0.50 & 0.52 & 1.17 & 0.92 \\
\hline Magnesium oxide & - & - & 0.08 & 0.04 \\
\hline Magnesium sulfate & 1.90 & 2.08 & 0.02 & - \\
\hline Sodium bicarbonate & - & - & 0.84 & 0.59 \\
\hline Mineral vitamin $\operatorname{mix}^{5}$ & 0.40 & 0.17 & 0.17 & 0.20 \\
\hline Vitamin $\mathrm{A}^{6}$ & - & 0.03 & 0.02 & 0.02 \\
\hline Vitamin $\mathrm{D}^{7}$ & - & 0.03 & - & - \\
\hline Vitamin $\mathrm{E}^{8}$ & 0.40 & 0.60 & - & - \\
\hline Biotin $^{9}$ & - & 0.70 & 0.42 & 0.32 \\
\hline Momensin ${ }^{10}$ & 0.01 & - & - & - \\
\hline Ethyl-cellulose RPM ${ }^{11}$ & - & 0.09 & 0.10 & 0.10 \\
\hline
\end{tabular}

${ }^{1}$ SoyPlus, West Central Soy (Ralston, IA).

${ }^{2}$ ProVAAl AADvantage, Perdue AgriBusiness (Salisbury, MD).

${ }^{3}$ West Central Soy.

${ }^{4}$ Energy Booster 100, Milk Specialties Global (Eden Prairie, MN).

${ }^{5}$ Contained a minimum of $5 \% \mathrm{Mg}, 10 \% \mathrm{~S}, 7.5 \% \mathrm{~K}, 2.0 \% \mathrm{Fe}, 3.0 \% \mathrm{Zn}, 3.0 \% \mathrm{Mn}, 5,000 \mathrm{mg}$ of Cu/kg, $250 \mathrm{mg}$ of I/ $\mathrm{kg}, 40 \mathrm{mg}$ of $\mathrm{Co} / \mathrm{kg}, 150 \mathrm{mg}$ of Se/kg, 2,200 kIU of vitamin A/kg, $660 \mathrm{kIU}$ of vitamin $\mathrm{D}_{3} / \mathrm{kg}$, and 7,700 $\mathrm{IU}$ of vitamin $\mathrm{E} / \mathrm{kg}$.

${ }^{6}$ Contained $30,000 \mathrm{kIU} / \mathrm{kg}$.

${ }^{7}$ Contained 5,000 kIU $/ \mathrm{kg}$.

${ }^{8}$ Contained 44,000 kIU/kg.

${ }^{9} \mathrm{ADM}$ Animal Nutrition (Quincy, IL).

${ }^{10}$ Rumensin, Elanco Animal Health (Greenfield, IN).

${ }^{11}$ Ethyl-cellulose rumen-protected methionine, Evonik Nutrition and Care GmbH (Hanau-Wolfgang, Germany). Added only in the treatment group.

method 990.03), NDF with heat-stable $\alpha$-amylase and sodium sulfite (Van Soest et al., 1991), ADF (Van Soest et al., 1991), and ether extract (AOAC International, 2000; method 2003.05) by Cumberland Valley Analytical Services (Hagerstown, MD). Evonik Nutrition and Care $\mathrm{GmbH}$ analyzed feed ingredients for AA (AOAC International, 1995). The values for $\mathrm{NE}_{\mathrm{L}}, \mathrm{RUP}$, and RDP were predicted using the NRC (2001) model. We used the mean chemical composition of feed ingredients throughout the experiment to evaluate prepartal and postpartal diets using the NRC (2001) model. Feed offered and refused was recorded daily throughout the entire experiment.

Milk production was recorded daily, and consecutive morning, midday, and evening samples were collected once a week, composited in proportion to milk yield, and stored with preservative at $4^{\circ} \mathrm{C}$ before analysis of fat, protein, lactose, and MUN by mid-infrared procedures (Dairy Lab Services, Dubuque, IA). Based on milk sample analysis, the $3.5 \% \mathrm{ECM}$ and $\mathrm{FCM}$ were calculated as follows:

$$
\begin{gathered}
\mathrm{ECM}=[12.82 \times \text { fat yield }(\mathrm{kg})] \\
+[7.13 \times \text { protein yield }(\mathrm{kg})] \\
+[0.323 \times \text { milk yield }(\mathrm{kg})] ; \\
\mathrm{FCM}=[0.4324 \times \text { milk yield }(\mathrm{kg})] \\
+[16.216 \times \text { milk fat }(\mathrm{kg})] .
\end{gathered}
$$

Body weight and BCS were recorded weekly throughout the entire experiment. Body condition was scored 
Table 2. Nutrient composition (mean \pm SD) and diet evaluation using NRC (2001) of prepartal and postpartal diets fed to multiparous Holstein cows supplemented with ethyl-cellulose rumen-protected methionine (RPM)

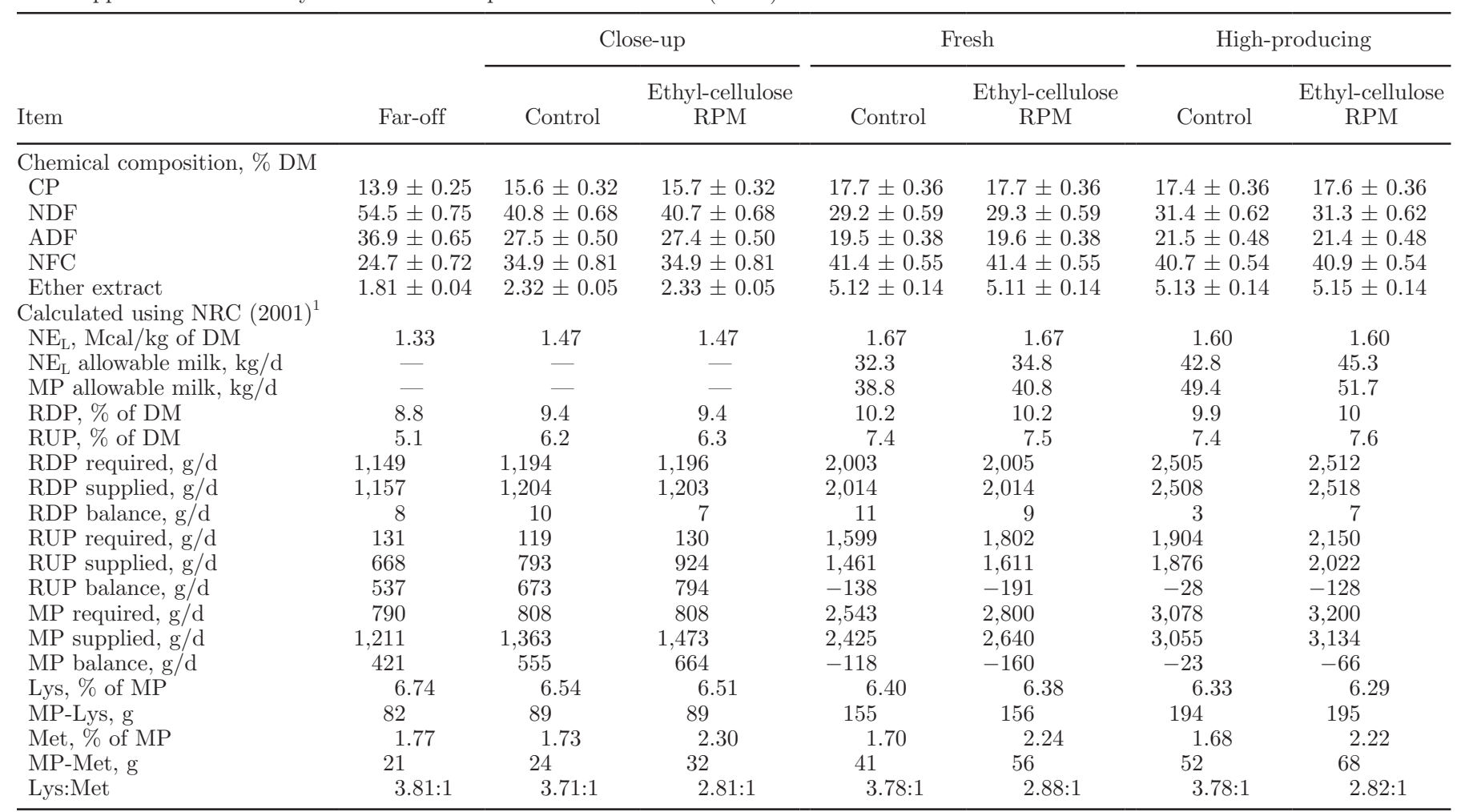

${ }^{1}$ The NRC (2001) evaluation of diets was based on final averaged pre- and postpartum DMI, production data, and feed analysis.

on a 5 -point scale $(1=$ thin, $5=$ fat $)$ as described by Wildman et al. (1982).

Feed efficiency was calculated by dividing milk yield by DMI, 3.5\% ECM by DMI, and FCM by DMI. The energy balance was calculated for each cow using equations from Hardie et al. (2015). Net energy intake was determined using the average weekly DMI multiplied by net energy density of the diet. Net energy of maintenance was calculated as $\mathrm{NE}_{\mathrm{M}}=\mathrm{BW} 0.75 \times 0.080$. Requirements of milk net energy were calculated as $\mathrm{NE}_{\mathrm{L}}=(0.0929 \times$ fat $\%+0.0547 \times$ protein $\%+0.0395$ $\times$ lactose $\%) \times$ milk yield. Postpartum energy balance $(\mathrm{Mcal} / \mathrm{d})$ was calculated as net energy intake $-\left(\mathrm{NE}_{\mathrm{L}}\right.$ $\left.+\mathrm{NE}_{\mathrm{M}}\right)$.

Blood was sampled from the coccygeal vessel before the a.m. feeding in 15 cows per treatment at $\mathrm{d}$ $-30,-14,1,7,21,30$, and 60 relative to calving date. This subset of cows was chosen based on absence of clinical disease. Samples were collected into evacuated tubes (BD Vacutainer, BD and Co., Franklin Lakes, NJ) containing lithium heparin. After blood collection, samples were placed on ice until centrifugation $(\sim 40 \mathrm{~min})$. Plasma was obtained by centrifugation at $2,000 \times g$ for $30 \mathrm{~min}$ at $4^{\circ} \mathrm{C}$. Aliquots of plasma were frozen $\left(-80^{\circ} \mathrm{C}\right)$ until further analysis. Glucose (catalog no. 0018250840), urea (catalog no. 0018255440), and $\gamma$-glutamyl transferase (GGT; catalog no. 0018257640) were analyzed using the IL Test purchased from Instrumentation Laboratory Spa (Werfen Co., Milan, Italy) in the ILAB 600 clinical autoanalyzer (Instrumentation Laboratory, Lexington, MA). Nitric oxide and constituents (nitrite and nitrate) were determined according to methods previously described by Trevisi et al. (2013). Fatty acids and BHB were measured using kits from Wako Chemicals (Richmond, VA) and Randox Laboratories Ltd. (Crumlin, United Kingdom), respectively, following the procedures described previously (Bionaz et al., 2007; Trevisi et al., 2012).

Minerals were extracted by adding $0.3 \mathrm{~mL}$ of trichloracetic acid $(10 \% \mathrm{vol} / \mathrm{vol})$ to $0.3 \mathrm{~mL}$ of plasma, and the sample was mixed and centrifuged at 3,500 $\times g$ for $10 \mathrm{~min}$ at $4^{\circ} \mathrm{C}$. A volume of $0.3 \mathrm{~mL}$ of supernatant was added to $2.7 \mathrm{~mL}$ of Millipore (Billerica, MA) water and mixed. Concentrations of $\mathrm{Ca}, \mathrm{Cl}, \mathrm{K}, \mathrm{Mg}, \mathrm{Na}$, $\mathrm{P}$, and $\mathrm{Zn}$ in the final solution were determined with an inductively coupled plasma optical emission spectrometer (ICP-OES 5100, Agilent Technologies, Santa Clara, CA) fitted with a cyclonic chamber in which 
samples were introduced with SeaSpray nebulizer (Agilent Technologies). Accuracy of the results was verified using a mineralized solution of SRM 1577b (National Institute of Standards and Technology, Gaithersburg, MD).

Liver was sampled via puncture biopsy (Dann et al., 2005) from 10 cows per treatment. Cows were chosen based on previous 305-d milk yield, BCS, absence of clinical disease, and enrollment for blood samples. Samples were collected from the same cows under local anesthesia at approximately $0800 \mathrm{~h}$ on $\mathrm{d}-21,-10$, 1 , and 10 relative to parturition. Liver was frozen immediately in liquid $\mathrm{N}$ and stored $\left(-80^{\circ} \mathrm{C}\right)$ until further analysis for concentration of triacylglycerol (TAG) as described by Zhou et al. (2016b).

\section{Statistical Analysis}

The production data were analyzed separately for prepartum, fresh (from 1 to $30 \mathrm{~d}$ postpartum), and high-producing (from 31 to $60 \mathrm{~d}$ postpartum) periods. All weekly data were analyzed using the MIXED procedure of SAS version 9.4 (SAS Institute Inc., Cary, $\mathrm{NC}$ ) according to the following model with repeated measures:

$$
Y_{i j k l}=\mu+b_{i}+M_{j}+T_{k}+M T_{j k}+c_{l}\left(b_{i}\right)+e_{i j k l},
$$

where $Y_{i j k l}=$ dependent continuous variable, $\mu=$ overall mean, $b_{i}=$ random effect of block $(i=1-7), M_{j}=$ fixed effect of treatment ( $j=$ control vs. ethyl-cellulose RPM), $T_{k}=$ fixed effect of time (days or weeks), $M T_{j k}$ $=$ interaction between treatment and time, $c_{l}\left(b_{i}\right)=$ random effect of cow within block, and $e_{i j k l}=$ residual error. The covariates for parity, previous 305-d milk

Table 3. Health incidents (no.) in multiparous Holstein cows fed the control diet or ethyl-cellulose rumen-protected methionine (RPM) during the close-up (from $-28 \mathrm{~d}$ to parturition), fresh (from 1 to 30 DIM), and high-producing (from 31 to 60 DIM) periods

\begin{tabular}{lcc}
\hline Item & Control & Ethyl-cellulose RPM \\
\hline Close-up period & 1 & 0 \\
$\quad$ Lameness & 8 & 7 \\
Postpartum d 1-30 & 1 & 1 \\
Ketosis $^{1}$ & 1 & 2 \\
$\quad$ Lameness & 1 & 0 \\
Mastitis & 7 & 8 \\
Milk fever & 2 & 1 \\
Retained placenta & & \\
$\quad$ Displaced abomasum & & 1 \\
Postpartum d 31-60 & 0 & 0 \\
$\quad$ Lameness (traumatic origin) & 1 & \\
$\quad$ Mastitis & & \\
\hline
\end{tabular}

${ }^{1}$ Defined as cows having large ketone concentration $(>80 \mathrm{mg} / \mathrm{dL})$ in urine; tested once a day.

${ }^{2}$ Defined as fetal membranes retained $\geq 24 \mathrm{~h}$ after calving. yield, and BCS at $-30 \mathrm{~d}$ relative to parturition were kept in the model for all variables when significant $(P$ $\leq 0.15)$. For the analysis of prepartum DMI, the average DMI of individual cows during the far-off period was used as a covariate in the model, whereas plasma data at $-30 \mathrm{~d}$ relative to parturition was included as a covariate for the blood biomarker analyses. Unless otherwise specified, first-order autoregressive was the covariate structure used for analysis because it resulted in the lowest Bayesian information criterion for most of the variables measured. Normality of the residuals was checked with normal probability and box plots. Treatment differences within week were analyzed using the SLICE option. Cumulative milk yield and DMI were analyzed using the MIXED procedure of SAS using the model described above without time effect. Significance was determined at $P \leq 0.05$, and tendencies were determined at $P \leq 0.10$.

All cows were in apparent good health at the beginning of the study, and treatment groups were not different in terms of previous 305-d milk yield $(P=$ $0.47)$ or BW $(P=0.51)$ and BCS $(P=0.39)$ at $-30 \mathrm{~d}$ prepartum. One of the cows in the control group had lameness with traumatic origin at 37 DIM; thus, the data of the last $2 \mathrm{wk}$ and the cumulative milk yield and cumulative DMI during the high-producing period were excluded from the statistical analyses. All other data were included.

\section{RESULTS}

\section{Health}

The incidence of disorders is summarized in Table 3. Ketosis and retained placenta were the most frequent health issues; however, their occurrence was similar between treatments. The incidence of retained placenta was higher (67\% of total cases) during July and August 2016.

\section{Diets}

The ingredient composition of the diets is presented in Table 1. The nutrient composition (Table 2) was determined by analyzing each individual feed ingredient for its chemical composition and then entering the feed analysis results into the NRC (2001) model.

\section{Close-Up DMI}

Cows in the ethyl-cellulose RPM group had greater $(P<0.01)$ DMI during the close-up period (average $=1.2 \mathrm{~kg} / \mathrm{d})$ and consequently had greater $(P=0.01)$ cumulative DMI compared with the control (Table 4; Figure 1). The DMI in both groups progressively de- 
Table 4. Effects of ethyl-cellulose rumen-protected methionine (RPM) supplementation to multiparous Holstein dairy cows during the close-up (from -28 d to parturition), fresh (from 1 to 30 DIM), and high-producing (from 31 to 60 DIM) periods on DMI and production

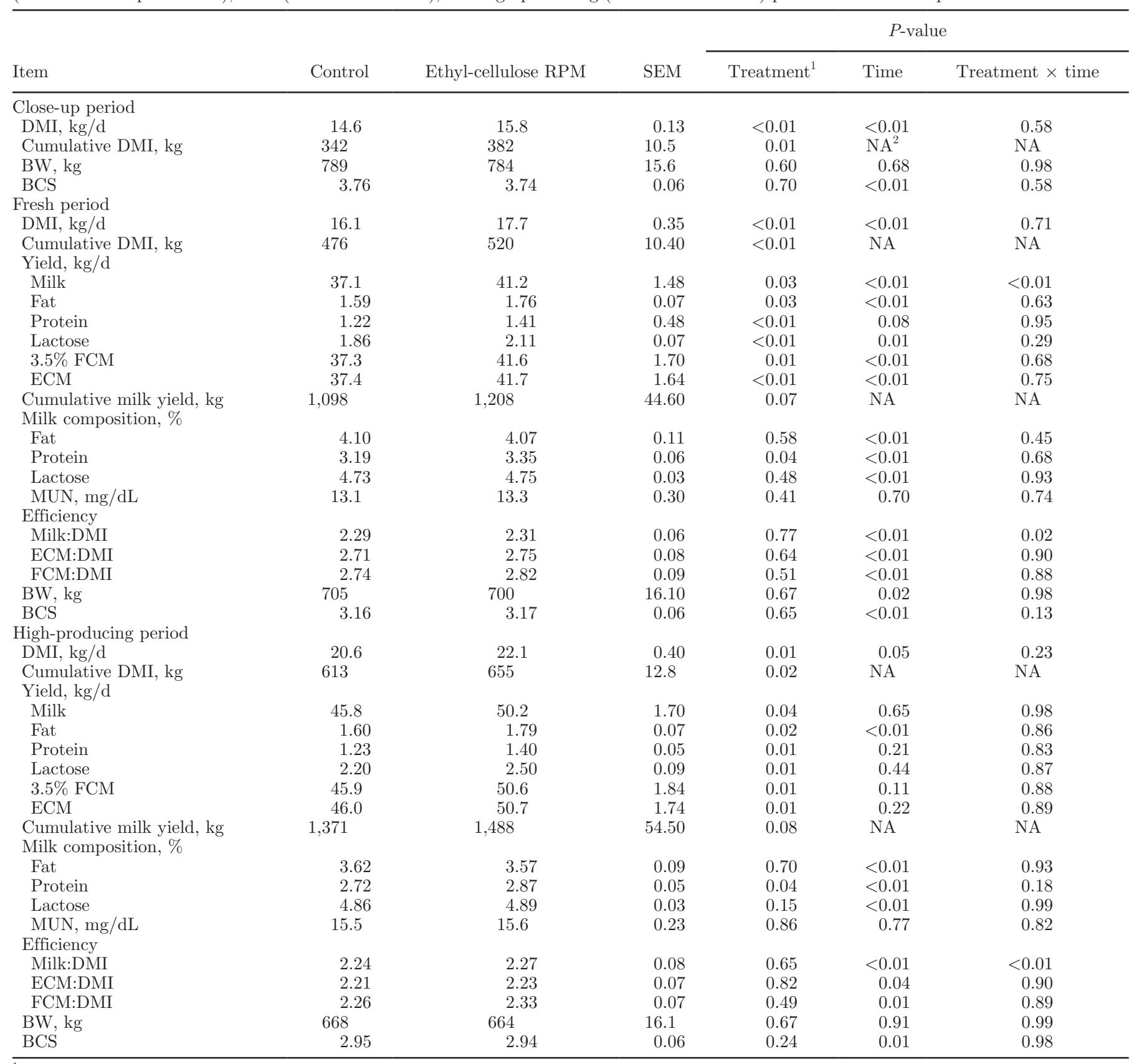

${ }^{1}$ Ethyl-cellulose RPM effect.

${ }^{2} \mathrm{NA}=$ not applicable.

creased from $-10 \mathrm{~d}$ to parturition. No differences $(P=0.03)$, fat yield $(+0.17 \mathrm{~kg} / \mathrm{d} ; P=0.03)$, milk protein $>0.10)$ between treatments were observed for BW and BCS.

\section{Fresh Period Production Responses}

Ethyl-cellulose RPM supplementation led to greater $(P<0.01)$ DMI $(+1.65 \mathrm{~kg} / \mathrm{d})$, milk yield $(+4.1 \mathrm{~kg} / \mathrm{d} ; P$ yield $(+0.2 \mathrm{~kg} / \mathrm{d} ; P<0.01)$, milk lactose yield $(+0.25$ $\mathrm{kg} / \mathrm{d} ; P=0.01), 3.5 \%$ FCM $(+4.3 \mathrm{~kg} / \mathrm{d} ; P=0.01)$, and ECM $(+4.4 \mathrm{~kg} / \mathrm{d} ; P<0.01$; Table 4 ; Figures 1 and 2). A treatment $\times$ time interaction $(P<0.01)$ was observed for milk yield due to a greater increase throughout the experiment in cows supplemented with ethyl-cellulose RPM. In addition, cows in the ethyl- 

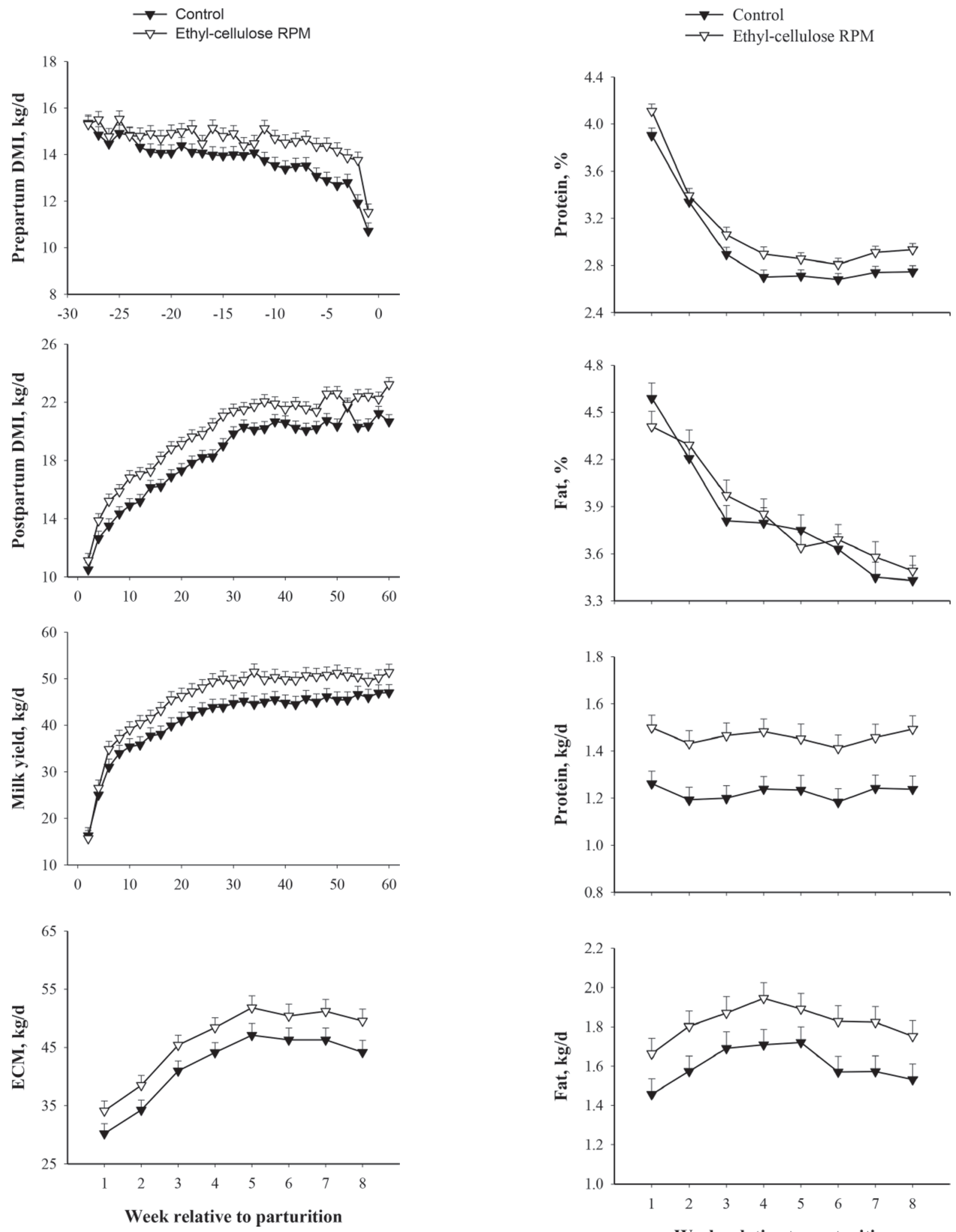

Figure 1. Effects of ethyl-cellulose rumen-protected methionine (RPM) supplementation to multiparous Holstein cows from -28 through 60 DIM on prepartum DMI (last $28 \mathrm{~d}$ of pregnancy), postpartum DMI (from 1 to 60 DIM), milk yield, and ECM. Error bars represent SEM.
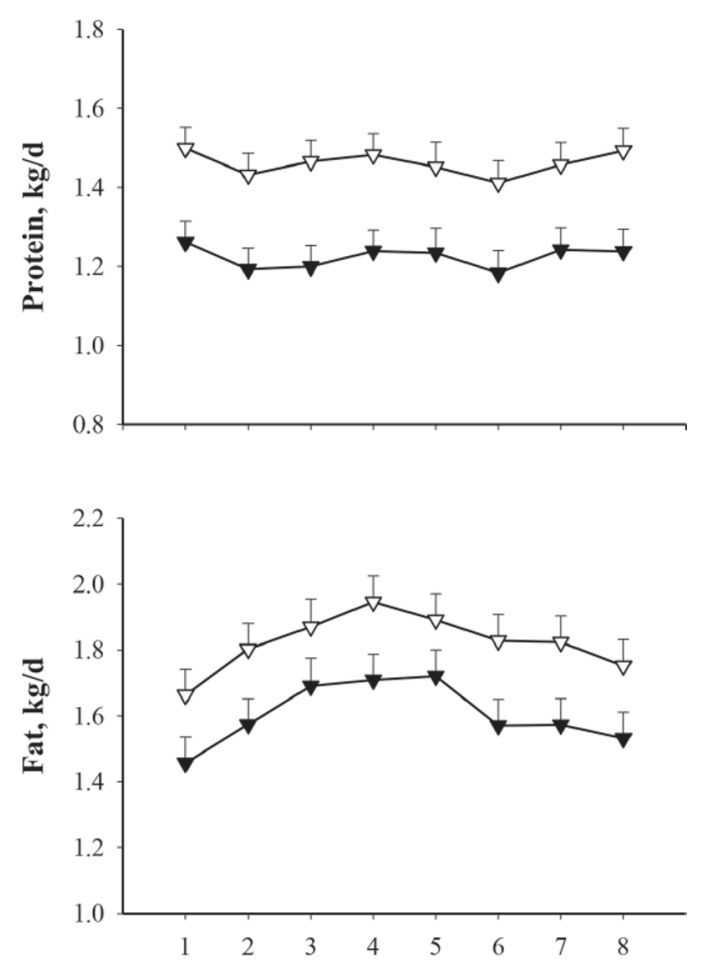

Week relative to parturition

Figure 2. Effects of ethyl-cellulose rumen-protected methionine (RPM) supplementation to multiparous Holstein cows from -28 through 60 DIM on milk fat and milk protein content and yield. Error bars represent SEM. 
cellulose RPM group had greater cumulative DMI $(P<$ $0.01)$ and tended $(P=0.07)$ to have greater cumulative milk yield.

Although cows in the ethyl-cellulose RPM group had greater $(P=0.04)$ milk protein content $(+0.16$ percentage units), no differences $(P>0.10)$ were observed for milk fat, lactose, and MUN. Furthermore, no differences $(P>0.10)$ were observed for feed efficiency, BW, and BCS. As expected, over time both groups of cows experienced increases in DMI and the yield of milk and milk components, but BW and BCS decreased.

\section{High-Producing Period Responses}

Ethyl-cellulose RPM supplementation led to greater $(P=0.01)$ DMI $(+1.45 \mathrm{~kg} / \mathrm{d})$, milk yield $(+4.4 \mathrm{~kg} / \mathrm{d} ; P$ $=0.04)$, fat yield $(+0.19 \mathrm{~kg} / \mathrm{d} ; P=0.02)$, milk protein yield $(+0.17 \mathrm{~kg} / \mathrm{d} ; P=0.01)$, milk lactose yield $(+0.30$ $\mathrm{kg} / \mathrm{d} ; P=0.01), 3.5 \%$ FCM $(+4.7 \mathrm{~kg} / \mathrm{d} ; P=0.01)$, and ECM $(+4.8 \mathrm{~kg} / \mathrm{d} ; P=0.01$; Table 4 ; Figure 1 and 2$)$. In addition, cows in ethyl-cellulose RPM had greater cumulative DMI $(P=0.02)$ and tended to have greater cumulative milk yield $(P=0.08)$. Although cows in ethyl-cellulose RPM had greater $(P=0.04)$ milk protein content $(+0.15$ percentage units $)$, no differences $(P$ $>0.10)$ were observed for milk fat, lactose, and MUN. Furthermore, no differences $(P>0.10)$ were observed for feed efficiency, BW, and BCS.

\section{Energy Balance}

During the fresh period, cows in the ethyl-cellulose RPM group had net energy intakes that were $2.9 \mathrm{Mcal} / \mathrm{d}$ greater and milk energy outputs that were $4 \mathrm{Mcal} / \mathrm{d}$ greater compared with controls $(P<0.01$; Table 5$)$. No differences $(P>0.10)$ in energy partitioned to maintenance and energy balance were observed. As lactation progressed, cows increased energy intake, and negative energy balance was ameliorated (Figure 3).

In the high-producing period, ethyl-cellulose RPM cows had greater energy intake $(+2.4 \mathrm{Mcal} / \mathrm{d} ; P<$ $0.01)$ and milk energy output $(+2.8 \mathrm{Mcal} / \mathrm{d} ; P=0.05)$. However, no differences $(P>0.10)$ in energy allocated to maintenance and energy balance were observed between treatments.

\section{Biomarkers in Plasma and Liver TAG}

Compared with controls, ethyl-cellulose RPM cows had lower concentrations of GGT $(P=0.03)$ and tended to have lower concentrations of fatty acids $(P=$ $0.08)$. No differences $(P>0.10)$ between groups were observed for blood glucose, BHB, urea, nitric oxide, $\mathrm{NO}_{2}, \mathrm{NO}_{3}$, liver TAG, and mineral concentrations (Table 6; Figure 4; Supplemental Figures S1 and S2, https://doi.org/10.3168/jds.2017-12689).

\section{DISCUSSION}

\section{Nutrient Composition and NRC Evaluation of Diets}

The NRC (2001) model assumes that the MP supply is first used to meet maintenance requirements, which are a function of BW (endogenous urinary and scurf proteins) and DMI (endogenous MP and metabolic fecal protein). The remainder is used for productive functions such as gestation, growth, and milk protein synthesis (Arriola Apelo et al., 2014). Corroborating results from previous studies using different sources of RPM, the MP balance was positive prepartum and negative postpartum regardless of treatment (Osorio et al., 2013). Considering that there was no difference in cow BW prepartum, it was expected that RPMsupplemented cows had a more positive MP balance

Table 5. Effects of ethyl-cellulose rumen-protected methionine (RPM) supplementation to multiparous Holstein dairy cows during the close-up (from $-28 \mathrm{~d}$ to parturition), fresh (from 1 to $30 \mathrm{DIM}$ ), and highproducing (from 31 to 60 DIM) periods on net energy (NE) intake, milk energy, and energy balance

\begin{tabular}{|c|c|c|c|c|c|c|}
\hline \multirow[b]{2}{*}{ Item } & \multirow[b]{2}{*}{ Control } & \multirow[b]{2}{*}{ Ethyl-cellulose RPM } & \multirow[b]{2}{*}{ SEM } & \multicolumn{3}{|c|}{$P$-value } \\
\hline & & & & Treatment $^{1}$ & Time & Treatment $\times$ time \\
\hline \multicolumn{7}{|l|}{$\overline{\text { Fresh period }}$} \\
\hline NE intake & 26.7 & 29.6 & 0.48 & $<0.01$ & $<0.01$ & 0.93 \\
\hline NE lactation & 29.2 & 33.2 & 1.05 & $<0.01$ & $<0.01$ & 0.95 \\
\hline NE maintenance & 10.3 & 10.5 & 0.24 & 0.57 & $<0.01$ & 0.73 \\
\hline Energy balance & -13.5 & -14.7 & 0.91 & 0.35 & $<0.01$ & 0.92 \\
\hline \multicolumn{7}{|c|}{ High-producing period } \\
\hline NE intake & 32.9 & 35.3 & 0.36 & $<0.01$ & 0.28 & 0.43 \\
\hline NE lactation & 31.2 & 34.0 & 1.12 & 0.05 & 0.43 & 0.99 \\
\hline NE maintenance & 10.3 & 10.5 & 0.24 & 0.57 & $<0.01$ & 0.73 \\
\hline Energy balance & -6.41 & -7.31 & 1.13 & 0.60 & 0.06 & 0.89 \\
\hline
\end{tabular}

${ }^{1}$ Ethyl-cellulose RPM effect. 
$\rightarrow$ Control

$\rightarrow-$ Ethyl-cellulose RPM
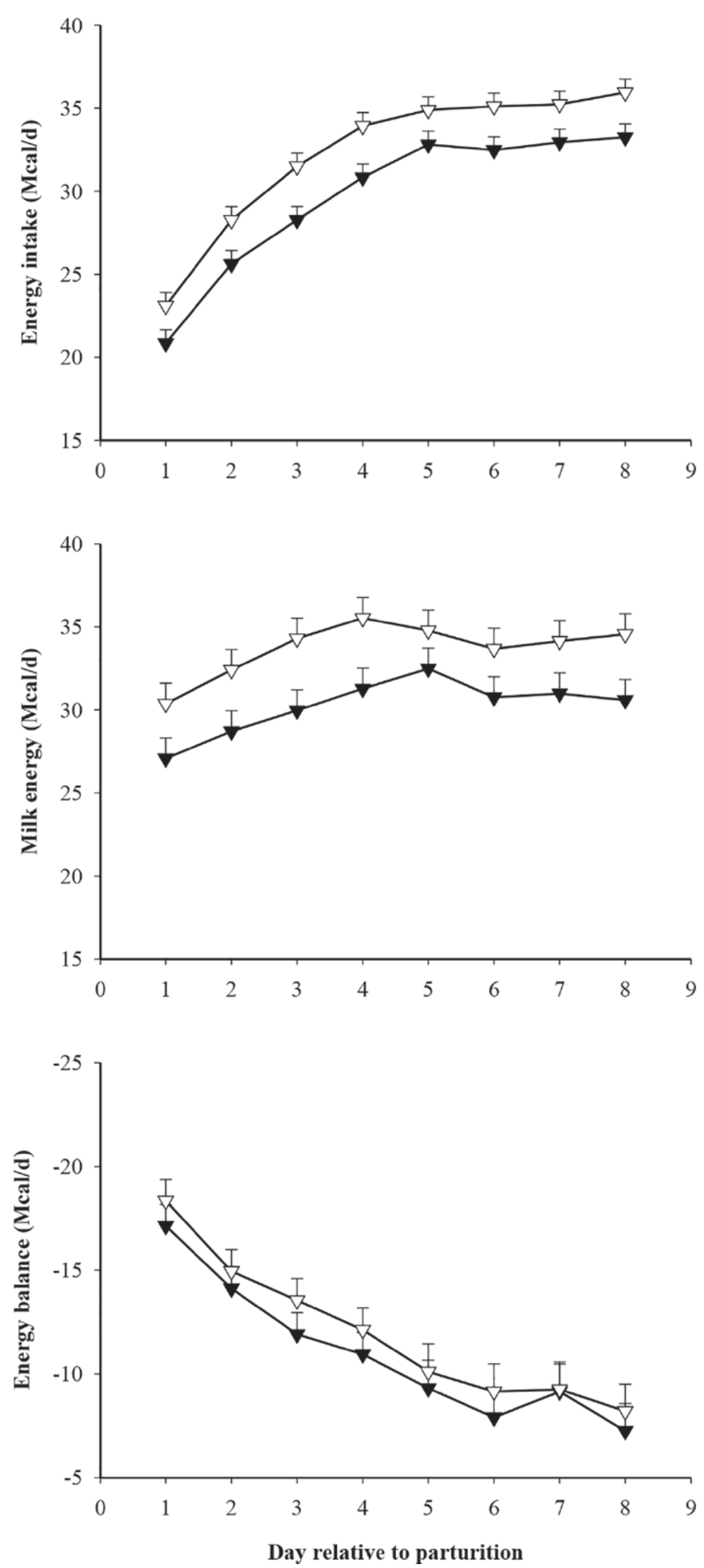

Figure 3. Effects of ethyl-cellulose rumen-protected methionine (RPM) supplementation to multiparous Holstein cows from -28 through 60 DIM on energy intake, milk energy, and energy balance. Error bars represent SEM. prepartum. This positive MP balance during the prepartum period was not only from the RUP but also from positive RDP values in both treatments.

Despite the greater estimated supply of MP in ethylcellulose RPM-supplemented cows, according to NRC (2001), a more negative MP balance was observed postpartum in this group. This was likely due to the greater MP required to sustain increases in milk and milk protein yield with ethyl-cellulose RPM supplementation. Postpartum, the estimated increase of MP requirement for cows fed ethyl-cellulose RPM was 257 and $122 \mathrm{~g} / \mathrm{d}$ for fresh and high-producing periods, respectively. The more negative protein balance in ethyl-cellulose RPM cows might have resulted in greater protein mobilization from muscle to match requirements. However, we did not observe differences in BW between groups throughout the study.

The duodenal supply of Lys and Met desired to maximize milk protein content and yield during established lactation has been suggested to be 7.2 and $2.4 \%$ of MP, respectively (NRC, 2001). In the present study, Lys was roughly constant at $6.5 \%$ of MP, whereas ethylcellulose RPM supplementation increased Met from 1.70 to $2.25 \%$ of MP on average. Also, we estimated that ethyl-cellulose RPM supplementation decreased the duodenal Lys:Met ratio from 3.78, 3.71, and 3.71 in the prepartum, fresh, and high-production periods, respectively, to $2.81: 1,2.88: 1$, and 2.82:1.

\section{DMI}

Previous studies with RPM supplementation have resulted in inconsistent responses in DMI (Ordway et al., 2009; Chen et al., 2011; Osorio et al., 2013). For instance, Patton (2010) compiled data from 35 studies in which RPM was fed and reported a high heterogeneity in the DMI response, which indicated that other factors such as differences in level of RPM supplementation, length of feeding period, or stage of lactation likely confounded the results. In our study, ethyl-cellulose RPM supplementation increased DMI not only in the prepartum and immediate postpartum periods as previously observed (i.e., Osorio et al., 2013; Zhou et al., 2016b) but also when fed in the high-producing period up to 60 DIM.

The consistently greater DMI in RPM-fed cows during the transition period has been associated with better immunometabolic status, a reduction in inflammation and oxidative stress status, and better liver function (Osorio et al., 2014; Zhou et al., 2016a). The lower concentration of the enzyme GGT could be considered one indicator (Bertoni et al., 2008) of better liver function in ethyl-cellulose RPM-fed cows. Previously, Zhou et al. $(2016 \mathrm{a}, \mathrm{b})$ demonstrated that cows with better liver 
function had greater DMI. Hence, the positive effect of ethyl-cellulose RPM on liver function can explain, at least in part, the greater DMI.

In the context of feed intake regulation, the hepatic energy status has been proposed as a major regulator in dairy cows - that is, as hepatic oxidative fuel supply increases, the brain is signaled via the vagal afferent nerve to reduce intake (Allen et al., 2009). Although it is thought that propionate and fatty acids are primary fuels that cause hypophagia in ruminants (Allen et al., 2009), more recent data suggest that fatty acids are the most quantitatively important hepatic oxidative substrates during the peripartal period (McCarthy et al., 2015a,b). Thus, the tendency for a greater concentration of fatty acids in early lactation in the control group could have been associated with an increase in acetyl CoA oxidized within the tricarboxylic acid cycle (Drackley et al., 2001) and may have been one of the causes for the lower DMI compared with ethyl-cellulose RPM-fed cows.

\section{Milk Production and Milk Composition}

Overall, RPM supplementation has resulted in inconsistent responses in milk yield (Ordway et al., 2009; Chen et al., 2011; Osorio et al., 2013). Previous studies did not detect increases in milk yield when RPM or Met analog was fed (Piepenbrink et al., 2004; Socha et al., 2005; Ordway et al., 2009; Preynat et al., 2009), whereas others observed positive responses when supplied until 30 DIM (Overton et al., 1996; Piepenbrink et al., 2004; Osorio et al., 2013; Sun et al., 2016; Zhou et al., 2016b). To our knowledge, our study is the first to demonstrate that RPM supplementation elicits a sustained increase in milk production from the immediate postpartum period $(+4.1 \mathrm{~kg} / \mathrm{d}$ until $30 \mathrm{DIM})$ through the peak of lactation $(+4.4 \mathrm{~kg} / \mathrm{d}$ from 30 to 60 DIM). This increase in milk yield is likely related to the greater DMI in ethyl-cellulose RPM-supplemented cows.

The increase in ECM from 4.3 to $4.7 \mathrm{~kg} / \mathrm{d}$ with ethylcellulose RPM supplementation between the fresh and high-producing periods was associated with positive effects on the yield of milk components (i.e., milk protein content and yield), which underscores the fact that milk protein early postpartum is directly affected by the adequacy of AA in the MP (NRC, 2001). From a meta-analysis, Patton (2010) observed that cows that were Met deficient responded to RPM supplementation with greater milk protein and milk fat yield. The milk protein response in the present study was similar to previous results from our group (Osorio et al., 2013; Zhou et al., 2016b). It is also noteworthy that the milk protein yield responses detected during the fresh period in the present study and in previous studies from our laboratory (Osorio et al., 2013; Zhou et al., 2016b) were greater (from 120 to $190 \mathrm{~g} / \mathrm{d}$ ) than the values reported by Patton (2010).

Similar to our current findings, a previous study using RPM (Osorio et al., 2013) detected an increase in milk fat yield. An unexplored area of EAA metabolism in dairy cows is the potential effect of these nutrients

Table 6. Effects of ethyl-cellulose rumen-protected methionine (RPM) supplementation to multiparous Holstein dairy cows during the closeup (from $-28 \mathrm{~d}$ to parturition), fresh (from 1 to $30 \mathrm{DIM}$ ), and high-producing (from 31 to 60 DIM) periods on blood biomarkers and liver triacylglycerol (TAG) concentrations

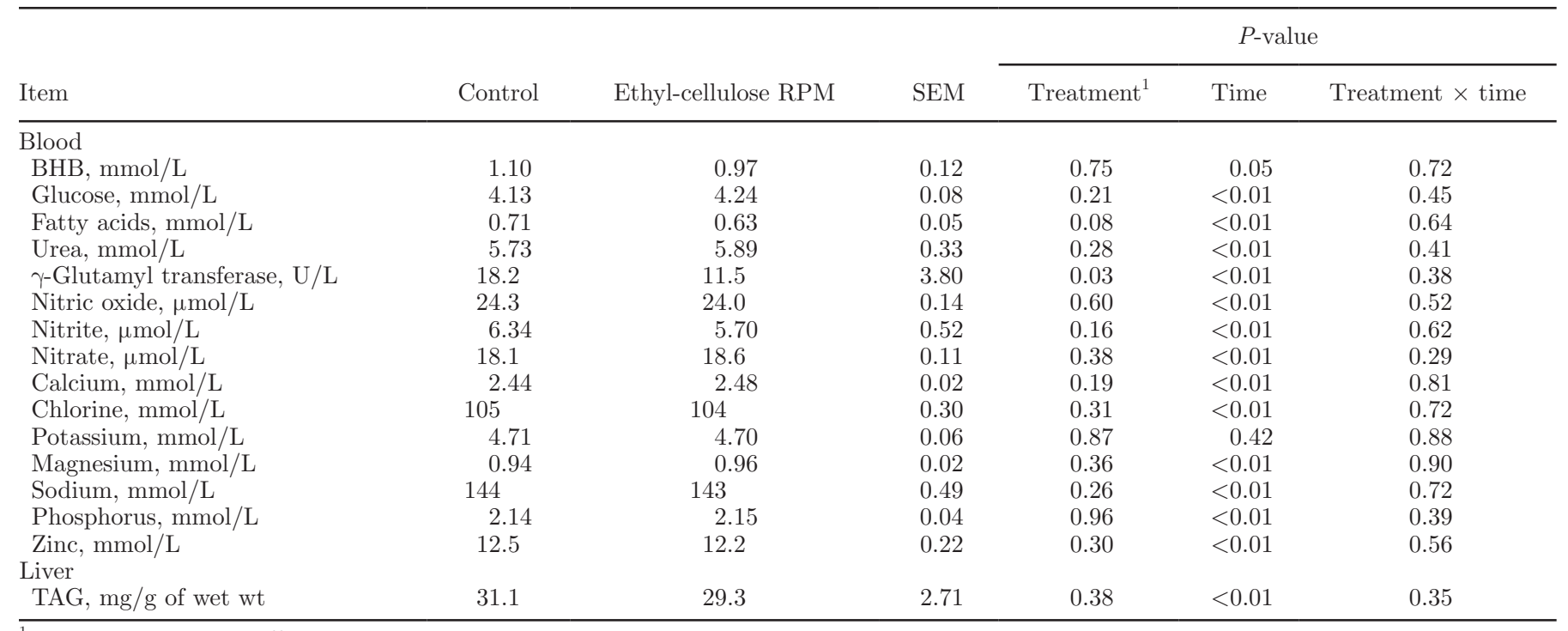

${ }^{1}$ Ethyl-cellulose RPM effect. 
$\rightarrow$ Control

$\rightarrow$ Ethyl-cellulose RPM
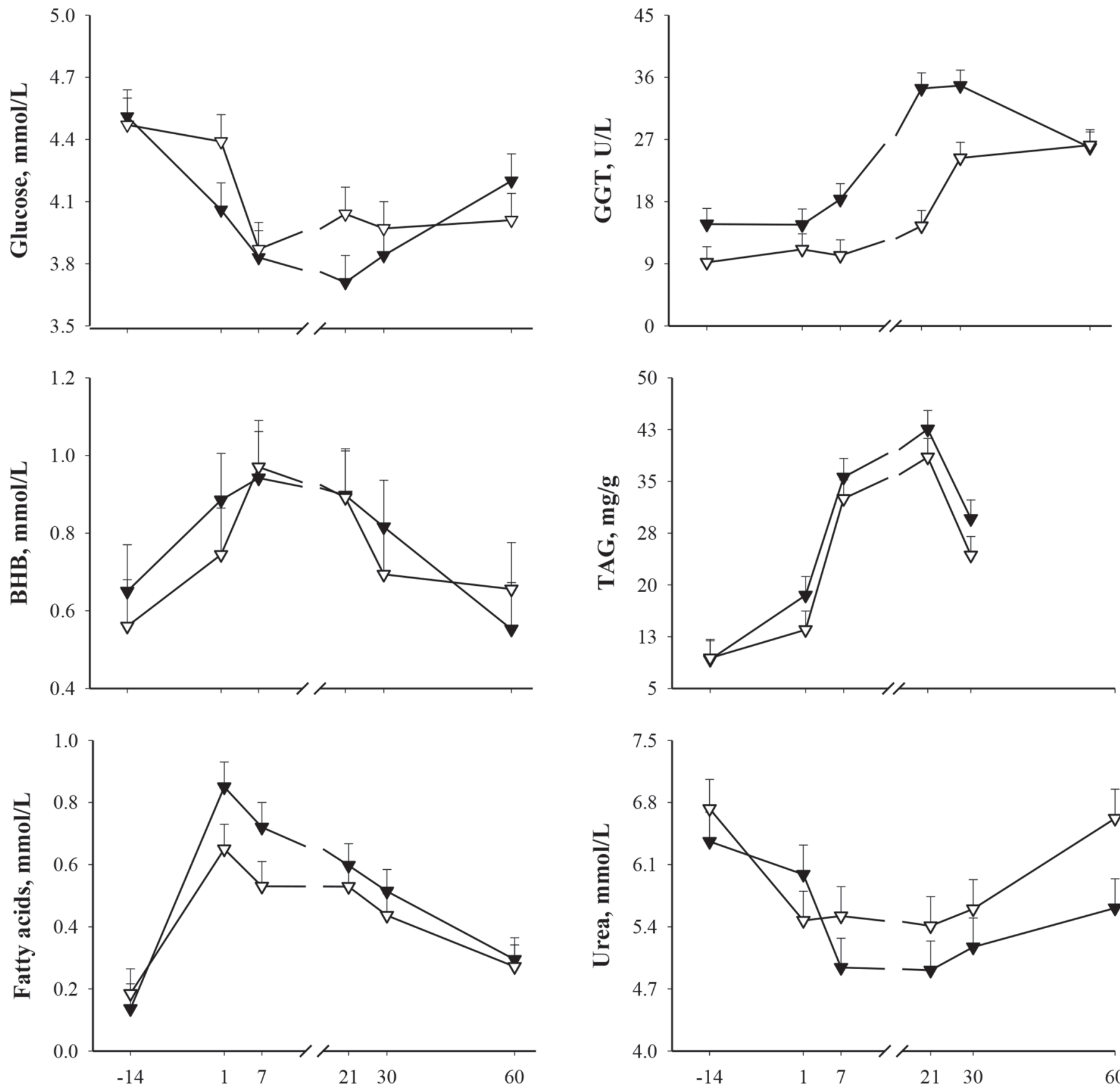

Day relative to parturition

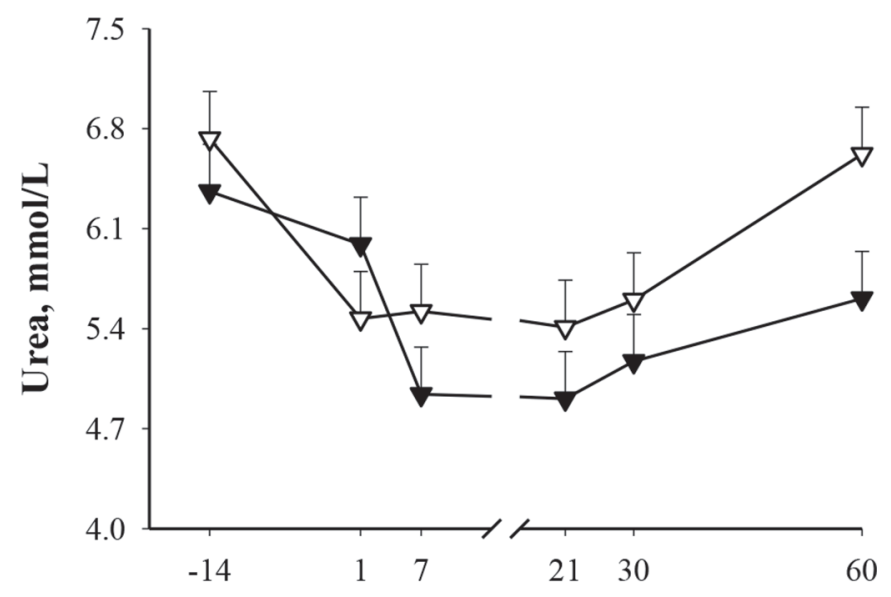

Day relative to parturition

Figure 4. Effects of ethyl-cellulose rumen-protected methionine (RPM) supplementation to multiparous Holstein cows from -28 through 60 DIM on blood glucose, BHB, fatty acids, urea and $\gamma$-glutamyl transferase (GGT), and liver triacylglycerol (TAG; from -14 to 21 DIM). Data for d 30 and 60 are included for comparison only. Error bars represent SEM.

on mRNA expression of lipogenic target genes. For instance, Li et al. (2016) using an in vitro model observed that an optimal AA balance stimulated the mRNA expression of enzymes related to de novo FA synthesis (ACACA, FASN) and desaturation (SCD), TAG synthesis (LPIN1), and transcription regulation of lipid 
synthesis (SREBF1, INSIG1) in bovine mammary cells. The effects of Met supplementation on regulation of mammary fatty acid synthesis deserve further investigation.

In our study, supplementation of ethyl-cellulose RPM increased energy intake but did not reduce negative energy balance compared with controls. This result was expected because we observed greater milk energy output in ethyl-cellulose RPM-supplemented cows due to the increase in milk yield and milk protein yield. A previous study (Gowanlock et al., 2015) reported a similar magnitude of negative energy balance when supplementing ethyl-cellulose RPM up to 30 DIM. In addition, the tendency for lower fatty acids and the lower GGT concentrations in ethyl-cellulose RPMsupplemented cows is indicative of an improvement in metabolic status, which has been associated with an increase in net energy efficiency due in part to a decrease in energy demands by the immune system (Trevisi et al., 2010; Kvidera et al., 2017).

\section{Metabolism Biomarkers and Liver TAG}

Epidemiological data have established a positive association between increased blood concentrations of fatty acids and BHB and negative health and production outcomes at both the individual cow and herd levels (Duffield et al., 2009; Ospina et al., 2013). In our study, although we did not observe differences between treatments for BHB concentration, ethyl-cellulose RPM supplementation tended to reduce fatty acid concentration. A recent study also reported lower fatty acid concentrations from 1 to 21 DIM in cows supplemented with ethyl-cellulose RPM (Sun et al., 2016). Therefore, it is reasonable to speculate that ethyl-cellulose RPMsupplemented cows in the present study were able to metabolize circulating fatty acids more efficiently either in the liver or through uptake by the mammary gland or other peripheral tissues.

\section{CONCLUSIONS}

Results indicate that feeding ethyl-cellulose RPM to achieve a Lys:Met ratio of 2.8:1 (0.09-0.10\% of diet $\mathrm{DM}$ ) during the periparturient period enhanced lactation performance from 1 to 60 DIM. The greater milk production was, at least in part, driven by the greater voluntary DMI and better liver function. To our knowledge, this is the first study reporting that ethyl-cellulose RPM supplementation starting from 4 wk prepartum improves performance not only in the immediate postpartum period but also through the peak of lactation.

\section{ACKNOWLEDGMENTS}

Fernanda Batistel was supported by a fellowship from Coordenação de Aperfeiçoamento de Pessoal de Nível Superior (CAPES, Brazilian Ministry of Education, Brasília, Brazil) and by Hatch funds under project ILLU-538-914, National Institute of Food and Agriculture (Washington, DC). We thank Perdue AgriBusiness (Salisbury, MD) for the donation of ProVAAl AADvantage during the course of the experiment.

\section{REFERENCES}

Allen, M. S., B. J. Bradford, and M. Oba. 2009. Board invited review: The hepatic oxidation theory of the control of feed intake and its application to ruminants. J. Anim. Sci. 87:3317-3334.

AOAC International. 1995. Official Methods of Analysis. 16th ed. Association of Official Analytical Chemists, Arlington, VA.

AOAC International. 2000. Official Methods of Analysis. 17th ed. Association of Official Analytical Chemists, Arlington, VA.

Arriola Apelo, S. I., J. R. Knapp, and M. D. Hanigan. 2014. Invited review: Current representation and future trends of predicting amino acid utilization in the lactating dairy cow. J. Dairy Sci. 97:4000-4017.

Bertoni, G., E. Trevisi, X. Han, and M. Bionaz. 2008. Effects of inflammatory conditions on liver activity in puerperium period and consequences for performance in dairy cows. J. Dairy Sci. 91:3300 3310 .

Bionaz, M., E. Trevisi, L. Calamari, F. Librandi, A. Ferrari, and G. Bertoni. 2007. Plasma paraoxonase, health, inflammatory conditions, and liver function in transition dairy cows. J. Dairy Sci. 90:1740-1750.

Chen, Z. H., G. A. Broderick, N. D. Luchini, B. K. Sloan, and E. Devillard. 2011. Effect of feeding different sources of rumen-protected methionine on milk production and $\mathrm{N}$-utilization in lactating dairy cows. J. Dairy Sci. 94:1978-1988.

Dann, H. M., D. E. Morin, G. A. Bollero, M. R. Murphy, and J. K. Drackley. 2005. Prepartum intake, postpartum induction of ketosis, and periparturient disorders affect the metabolic status of dairy cows. J. Dairy Sci. 88:3249-3264.

Drackley, J. K., T. R. Overton, and G. N. Douglas. 2001. Adaptations of glucose and long-chain fatty acid metabolism in liver of dairy cows during the periparturient period. J. Dairy Sci. 84(ESuppl.):E100-E112.

Duffield, T. F., K. D. Lissemore, B. W. McBride, and K. E. Leslie. 2009. Impact of hyperketonemia in early lactation dairy cows on health and production. J. Dairy Sci. 92:571-580.

Gowanlock, D. W., D. C. Mahan, J. S. Jolliff, and G. M. Hill. 2015. Evaluating the influence of National Research Council levels of copper, iron, manganese, and zinc using organic (Bioplex) minerals on resulting tissue mineral concentrations, metallothionein, and liver antioxidant enzymes in grower-finisher swine diets. J. Anim. Sci. 93:1149-1156.

Greenfield, R. B., M. J. Cecava, T. R. Johnson, and S. S. Donkin. 2000. Impact of dietary protein amount and rumen undegradability on intake, peripartum liver triglyceride, plasma metabolites, and milk production in transition dairy cattle. J. Dairy Sci. 83:703-710.

Hardie, L. C., L. E. Armentano, R. D. Shaver, M. J. VandeHaar, D. M. Spurlock, C. Yao, S. J. Bertics, F. E. Contreras-Govea, and K. A. Weigel. 2015. Considerations when combining data from multiple nutrition experiments to estimate genetic parameters for feed efficiency. J. Dairy Sci. 98:2727-2737.

Huyler, M. T., R. L. Kincaid, and D. F. Dostal. 1999. Metabolic and yield responses of multiparous Holstein cows to prepartum rumenundegradable protein. J. Dairy Sci. 82:527-536.

Kvidera, S. K., E. A. Horst, M. Abujamieh, E. J. Mayorga, M. V. Sanz Fernandez, and L. H. Baumgard. 2017. Glucose requirements of an 
activated immune system in lactating Holstein cows. J. Dairy Sci. 100:2360-2374.

Li, S., A. Hosseini, M. Danes, C. Jacometo, J. Liu, and J. J. Loor. 2016. Essential amino acid ratios and $\mathrm{mTOR}$ affect lipogenic gene networks and miRNA expression in bovine mammary epithelial cells. J. Anim. Sci. Biotechnol. 7:44.

McCarthy, M. M., T. Yasui, C. M. Ryan, G. D. Mechor, and T. R. Overton. 2015a. Performance of early-lactation dairy cows as affected by dietary starch and monensin supplementation. J. Dairy Sci. 98:3335-3350.

McCarthy, M. M., T. Yasui, C. M. Ryan, S. H. Pelton, G. D. Mechor, and T. R. Overton. 2015b. Metabolism of early-lactation dairy cows as affected by dietary starch and monensin supplementation. J. Dairy Sci. 98:3351-3365.

NRC. 2001. Nutrient Requirements of Dairy Cattle. 7th rev. ed. Natl. Acad. Press, Washington, DC.

Ordway, R. S., S. E. Boucher, N. L. Whitehouse, C. G. Schwab, and B. K. Sloan. 2009. Effects of providing two forms of supplemental methionine to periparturient Holstein dairy cows on feed intake and lactational performance. J. Dairy Sci. 92:5154-5166.

Osorio, J. S., P. Ji, J. K. Drackley, D. Luchini, and J. J. Loor. 2013 Supplemental Smartamine M or MetaSmart during the transition period benefits postpartal cow performance and blood neutrophil function. J. Dairy Sci. 96:6248-6263.

Osorio, J. S., E. Trevisi, P. Ji, J. K. Drackley, D. Luchini, G. Bertoni, and J. J. Loor. 2014. Biomarkers of inflammation, metabolism, and oxidative stress in blood, liver, and milk reveal a better immunometabolic status in peripartal cows supplemented with Smartamine M or MetaSmart. J. Dairy Sci. 97:7437-7450.

Ospina, P. A., J. A. McArt, T. R. Overton, T. Stokol, and D. V. Nydam. 2013. Using nonesterified fatty acids and beta-hydroxybutyrate concentrations during the transition period for herd-level monitoring of increased risk of disease and decreased reproductive and milking performance. Vet. Clin. North Am. Food Anim. Pract. $29: 387-412$.

Overton, T. R., D. W. LaCount, T. M. Cicela, and J. H. Clark. 1996. Evaluation of a ruminally protected methionine product for lactating dairy cows. J. Dairy Sci. 79:631-638.

Overton, T. R., and M. R. Waldron. 2004. Nutritional management of transition dairy cows: Strategies to optimize metabolic health. J. Dairy Sci. 87(E-Suppl.):E105-E119.

Patton, R. A. 2010. Effect of rumen-protected methionine on feed intake, milk production, true milk protein concentration, and true milk protein yield, and the factors that influence these effects: A meta-analysis. J. Dairy Sci. 93:2105-2118.

Piepenbrink, M. S., A. L. Marr, M. R. Waldron, W. R. Butler, T. R. Overton, M. Vazquez-Anon, and M. D. Holt. 2004. Feeding 2-hydroxy-4-(methylthio)-butanoic acid to periparturient dairy cows improves milk production but not hepatic metabolism. J. Dairy Sci. 87:1071-1084.
Preynat, A., H. Lapierre, M. C. Thivierge, M. F. Palin, J. J. Matte, A. Desrochers, and C. L. Girard. 2009. Influence of methionine supply on the response of lactational performance of dairy cows to supplementary folic acid and vitamin $\mathrm{B}_{12}$. J. Dairy Sci. 92:1685-1695.

Roche, J. R., J. K. Kay, A. G. Rius, T. M. Grala, A. J. Sheahan, H. M. White, and C. V. Phyn. 2013. Short communication: Immediate and deferred milk production responses to concentrate supplements in cows grazing fresh pasture. J. Dairy Sci. 96:2544-2550.

Schwab, C. G. 1995. Protected proteins and amino acids for ruminants. Pages 115-141 in Biotechnology in Animal Feeds and Animal Feeding. R. J. Wallace and A. Chesson, ed. VCH, New York, NY

Socha, M. T., D. E. Putnam, B. D. Garthwaite, N. L. Whitehouse, N A. Kierstead, C. G. Schwab, G. A. Ducharme, and J. C. Robert. 2005. Improving intestinal amino acid supply of pre- and postpartum dairy cows with rumen-protected methionine and lysine. J. Dairy Sci. 88:1113-1126

Sun, F., Y. Cao, C. Cai, S. Li, C. Yu, and Y. Yao. 2016. Regulation of nutritional metabolism in transition dairy cows: Energy homeostasis and health in response to post-ruminal choline and methionine. PLoS One 11:e0160659.

Trevisi, E., M. Amadori, S. Cogrossi, E. Razzuoli, and G. Bertoni. 2012. Metabolic stress and inflammatory response in high-yielding, periparturient dairy cows. Res. Vet. Sci. 93:695-704.

Trevisi, E., G. Bertoni, R. Lombardelli, and A. Minuti. 2013. Relation of inflammation and liver function with the plasma cortisol response to adrenocorticotropin in early lactating dairy cows. J. Dairy Sci. 96:5712-5722.

Trevisi, E., A. Zecconi, G. Bertoni, and R. Piccinini. 2010. Blood and milk immune and inflammatory responses in periparturient dairy cows showing a different liver activity index. J. Dairy Res. $77: 310-317$.

Van Soest, P. J., J. B. Robertson, and B. A. Lewis. 1991. Methods for dietary fiber, neutral detergent fiber, and nonstarch polysaccharides in relation to animal nutrition. J. Dairy Sci. 74:3583-3597.

Wildman, E. E., G. M. Jones, P. E. Wagner, R. L. Boman, H. F. Troutt Jr., and T. N. Lesch. 1982. A dairy cow body condition scoring system and its relationship to selected production characteristics. J. Dairy Sci. 65:495-501.

Zhou, Z., O. Bulgari, M. Vailati-Riboni, E. Trevisi, M. A. Ballou, F. C Cardoso, D. N. Luchini, and J. J. Loor. 2016a. Rumen-protected methionine compared with rumen-protected choline improves immunometabolic status in dairy cows during the peripartal period. J. Dairy Sci. 99:8956-8969.

Zhou, Z., M. Vailati-Riboni, E. Trevisi, J. K. Drackley, D. N. Luchini, and J. J. Loor. 2016b. Better postpartal performance in dairy cows supplemented with rumen-protected methionine compared with choline during the peripartal period. J. Dairy Sci. 99:8716-8732. 